\title{
IBM KELOMPOK PENGUSAHA TERASI DI DESA KRAMAT BUNGAH KABUPATEN GRESIK JAWA TIMUR
}

\author{
Anak Agung Sagung Alit Widyastuty ${ }^{1)}$, Indah Nurhayati ${ }^{2)}$, Susilowati ${ }^{3)}$ \\ ${ }^{1}$ Fakultas Tenik Sipil dan Perencanaan ${ }^{2}$ Fakultas Keguruan dan Ilmu Pendidikan \\ Universitas PGRI Adi Buana Surabaya \\ Email : adityawirayudha@yahoo.com
}

\begin{abstract}
ABSTRAK
Salah satu hasil perikanan yang melimpah di Desa Keramat Kecamatan Bungah kabupaten Gresik adalah udang rebon. Udang rebon pada saat musim penghujan melimpah tetapi pengusaha terasi belum bisa mengolah semua udang rebon yang ada dikarenakan belum mempunyai mesin menggiling uadang rebon. Pembuatan terasi belum memperhatihan kebersihan dan penjualannya terasi juga masih terbatas dikarenakan penjulanya melalui tengkulak dan tidak berlabel. Tujuan dari kegiatan IbM adalah memberikan ketrampilan dan pengetahuan kepada mitra tentang teknologi pembuatan terasi yang baik dan berkualitas, memberikan kesadaran kepada masyarakat akan pentingnya kebersihan dalam pengolahan makanan (terutama terasi) sehingga dapat menguangi resiko kesehatan bagi manusia, memberikan pengetahuan dan ketrampilan kepada mitra tentang penjualan dan pembukuan sederhana. Metode yang dilakukan dalam kegiatan ini adalah penyuluhan, pemberdayaan, pelatihan dan pendampingan kepada ibu-ibu PKK dan pengusaha terasi. Target dan luaran yang ingin dicapai pada kegiatan ini adalah pemberdayaan pengusaha terasi dalam memperluas pemasaran untuk meningkatkan kualitas dan produktifitas.Dari kegiatan in dapat disimpulkan pengusaha terasi dapat memproduksi terasi yang hygienis dengan menggunakan mesin dan diberinama branch baru, Terasi Mengare.
\end{abstract}

Kata Kunci : Terasi, Teknologi, Mengare

\section{PENDAHULUAN}

Sebagian besar wilayahnya Kab. Gresik merupakan dataran rendah dengan ketinggian antara 0 - 12 meter diatas permukaan laut kecuali sebagian kecil di bagian uatara (Kecamatan Panceng) mempunyai ketinggian sampai 25 meter di atas permukaan laut. Wilayah Kabupaten Gresik sebagain besar berupa pantai. Perikanan laut dan tambak merupakan komoditas utama kabupaten Gresik. Ragam potensi budi daya kelautan dan perikanan yang dapat dikembangkan di Kabupaten Gresik adalah ikan krapu, kerang, rajungan, bandeng, rumput laut dan udang.

Walaupun sebagian besar komoditi perikanan laut dimanfaatkan untuk peningkatan kebutuhan hidup masyarakat terutama dalam peningkatan gizi yang berasal dari protein hewan namun pendapatan masyarakat nelayan masih rendah. Selama ini masyarakat nelayan hanya melakukan kegiatan penangkapan di laut kemudian menjual begitu saja. Harga jual hasil tangkapan nelayan tergantung pada tengkulak yang menguasai harga perdagangan di tempat tersebut. Hampir $85 \%$ ibu- ibu nelayan belum mempunyai usaha sampingan untuk membantu perekonomian keluarga, mereka hanya mengandalkan hasil tangkapan para suami. hanya sekitar $15 \%$ ibu-ibu nelayan mempunyai usaha sampingan, yaitu : pengupasan rajungan, terasi, udang rebon, ikan asin dan krupuk ikan.

Desa Kramat Kecamatan Bungah Kabupaten Gresik Propinsi Jawa Timur (JATIM) merupakan desa yang terletak di pulau Mengare, dipinggiran pantai utara pulau Jawa. Warga masyarakat Desa Kramat $90 \%$ mempunyai mata pencaharian sebagai nelayan dan petani tambak. Pulau Mengare merupakan pulai kecil yang terdiri dari 3 Desa yaitu Tanjung Wedoro, Desa Kramat, dan Desa Watuagung.

Hasil tangkapan nelayan desa Kramat adalah ikan, rajungan dan udang. Cara penagkapan ikan nelayan masih tradisional dengan menggunakan perahu kayu. Nelayan ikan mendarat dipantai sekitar pukul 06.00 WIB. Hasil tangkapannya langsung dijual di Tempat Pelelangan Ikan (TPI) yang ada di Desa Kramat. Nelayan rajungan mendarat sekitar jam 10.00 WIB.

$$
\text { Hasil tangkapan rajungan }
$$
dikumpulkan oleh kelompok nelayan untuk 
selanjutnya dikupas dan dijual dalam bentuk daging. Nelayan udang mendarat pada pukul 12.00 WIB. Hasil tangkapan udang dikumpulkan kelompok nelayan selanjutnya dijual.

Setiap musim udang rebon, para nelayan desa Keramat dengan menggunakan alat tangkap jaring menyisir gerombolan udang rebon yang tampak kemerahan dari kejauhan menuju sekitar perairan dekat pemukiman mereka. Udang rebon yang sudah terjaring langsung dikeringkan, dan diolah sebagai bahan baku utama pembuatan terasi. Wanita nelayan Desa Keramat biasanya secara berkelompok melakukan kegiatan pengolahan terasi udang bersamasama.Terasi hasil olahan mereka murni terbuat dari udang rebon tanpa ditambah bahan apapun.

Selain Rajungan dan Udang sebagai komoditas utama nelayan desa Kramat, udang Rebon juga banyak dihasilkan di daerah ini. Udang Rebon kurang diminati nelayan karena harganya yang sangat murah yaitu sekitar $\mathrm{Rp} 1.000,-/ \mathrm{kg}$. Udang Rebon akan meningkat hasilnya terutama pada musim penghujan, yaitu sekitar Rp. 2.500,-kg/hari. Masyarakat setempat belum optimal dalam mengolah udang Rebon sebagai komoditas/bahan makanan yang mempunyai nilai jual dan nilai ekonomi yang tinggi. Udang Rebon oleh masyarakat setempat hanya dijemur sampai kering (selama 1 hari) kemudian ditumbuk. Udang yang sudah halus dijual ke tengkulak untuk bahan baku terasi. $1 \mathrm{~kg}$ udang Rebon tumbuk dijual dengan harga Rp. 15.000,- Proses pengolahan udang Rebon masih sangat sederhana. Sebelum udang Rebon dijemur tidak ada proses pemilahan udang yang segar dengan udang yang sudah membusuk, sehingga kualitas udang Rebon kering kurang bagus. Penjemuran dilakukan dengan menggunakan sinar matahari langsung dengan menggunakan alas dari anyaman bambu. Proses penjemuran kurang memperhatikan

a) Sebelum udang Rebon dijemur tidak dilakukan penyortiran udang yang segar dengan udang yang sudah membusuk, serta penyortiran terhadap kotoran yang ikut terbawa.

b) Penjemuran udang Rebon hanya mengandalkan sinar matahari kebersihan tempat penjemuran dan dalam tempat yang terbuka sehingga kemungkinan besar udang Rebon menjadi kotor pada saat dijemur.

Proses penghalusan udang Rebon kering juga masih sangat sederhana, hanya menggunakan lumpang batu dan penumbuk dengan menggunakan tenaga manusia. Tenaga kerja penumbuk kebanyakan ibu-ibu yang sudah cukup tua, usia sekitar 50 tahun 60 tahun, sehingga tenaganya sudah berkurang. Pada saat musim hujan pengusaha terasi mengalami kendala karena hasil udang Rebon sangat melimpah sedangkan cuaca kurang menguntungkan untuk penjemuran, dan tenaga untuk menumbuk udang yang kering juga kekurangan, sehingga udang Rebon banyak yang membusuk. Walaupun udang Rebon melimpah pada saat musim penghujan tetapi masyarakat belum bisa meningkatkan perekonomian masyarakat setempat. Gambar 4 sampai gambar 11 di bawah ini adalah gambar penjemuran, penumbukan udang Rebon dan hasil tumbukan udang Rebon menjadi terasi. Kondisi profil kelompok sasaran memberikan gambaran bahwa potensi pemberdayaan masyarakat sangat memungkinkan untuk dilaksanakan di desa Kramat kecamatan Bungah Kabupaten Gresik Jawa Timur. Mata pencaharian mayoritas masyarakat desa Kramat adalah nelayan. Meskipun perikanan merupakan komoditi yang telah dikenal masyarakat namun kehidupan mereka tidaklah membaik, karena mereka hanya menjual hasil tangkapan dan tidak memiliki upaya untuk diversifikasi usaha maupun upaya untuk meningkatkan nilai ekonominya. Selain itu mereka belum menyadari upaya untuk menjaga kebersihan dan kesehatan lingkungan. Berdasarkan hasil análisis yang dilakukan bersama mitra, permasalahan yang dihadapi mitra adalah :dang Rebon yang melimpah pada musim penghujan belum bisa terolah secara maksimal

langsung tanpa adanya rumah pelindung

c) Pengolahan pangan yang tidak memenuhi standar kesehatan dan keamanan pengolahan makanan

d) Penghalusan udang Rebon kering masing tradisional hanya menggunakan tenaga manusia 
menggunakan lesung dan alu sebagai penumbuk / menghaluskan udang tanpa mesin penggiling

e) Pengusaha terasi belum memahami teknologi pembuatan terasi yang baik dan berkualitas, sehingga pengusaha

Berdasarkan permasalahan diatas maka tujuan dari kegiatan ini adalah

a) Memberikan ketrampilan dan pengetahuan kepada mitra tentang teknologi pembuatan terasi yang baik dan berkualitas.

b) Memberikan kesadaran kepada masyarakat akan pentingnya

Kelompok sasaran dalam kegiatan ini adalah ibu-ibu dan pengusaha terasi di Desa Keramat. Metode pelaksanaan program $\mathrm{IbM}$ dialakukan dengan cara sebagai berikut :

1. Melakukan sosialisasi dan pendekatan dengan perangkat desa setempat untuk menentukan waktu pelaksanaan palatihan kepada warga masyarakat dan pengusaha terasi

2. Memotivasi warga masyarakat terutama ibu-ibu PKK untuk meningkatkan kemampuan dan ketrampian berwirausaha berbasis bahan baku lokal, yaitu pengolahan produk hasil laut sehingga dapat meningkatkan perekonomian lokal dan mengenalkan kepada masyarakat luar akan kekayaan pulau Mengare.

3. Untuk mengatasi permasalahan tentang pengolahan udang rebon menjadi terasi yang memenuhi standart keamanan pangan dan masyarakat dapat memperoleh manfaat secara ekonomis dilakukan kegiatan sebagai berikut: (a) memberikan penyuluhan kepada pengusaha terasi dan ibu-ibu PKK tentang cara pembuatan terasi dari udang rebon dan pentingnya kebersihan peralatan serta kebersihan pekerja dalam memproduksi terasi udang, (b) memberikan pelatihan dan pendampingan pembuatan terasi udang dengan menggunakan mesin penghancur udang. hanya menjual rebon yang sudah dihaluskan belum menjadi terasi.

f) Dokumentasi data keuangan belum tertata sehinggga menyulitkan dalam pengembangan usaha untuk memperoleh peminjaman modal untuk pengembangan usaha.

kebersihan dalam pengolahan makanan (terutama terasi) sehingga dapat menguangi resiko kesehatan bagi manusia.

c) Memberikan pengetahuan dan ketrampilan kepada mitra tentang penjualan dan pembukuan sederhana

\section{METODE PELAKSANAAN}

4. Untuk mengatasi permasalahn tentang pemberdayaan pengusaha terasi dalam memperluas pemasaran dan meningkatkan produktifitas dilakukan kegiatan berupa pelatihan dan pendampingan tata cara pengemasan terasi, pembuatan label terasi, strategi pemasaran secara on line dengan internet sebagai salah satu media promosi untuk memperluas pemasaran dan pembukuan sederhana.

\section{HASIL DAN PEMBAHASAN}

Hasil yang dicapai dalam pelaksanaan Iptek Bagi Masyarakat Kelompok Pengusaha Terasi di Desa Keramat Kecamatan Bungah Kabupaten Gresik yang dilakukan oleh Tim IbM dari Universitas PGRI Adi Buana Surabaya ada 8 kegiatan. Seluruh kegiatan sosialisasi dan pelatihan dilakukan di Balai Desa Keramat dan diikuti oleh sebagaian Ibu-Ibu PKK dan pengusaha terasi. Kegiatan IbM tersebut meliputi :

\section{Sosialisasi Kepada Aparat Desa.}

Tujuan dari kegiatan ini ada memberikan informasi kepada perangkat desa bahwa ada tim IbM yang akan mengadakan kegiatan di Desa Keramat dengan sasaran Ibu-Ibu PKK dan pengusaha terasi. Pada saat sosialisasi Perangkat Desa merasa senang dan antusias untuk mendukung semua kegiatan IbM. 
Pada kegiatan ini Tim bersama aparat Desa menyusun jadwa kegiatan dan teknis pelaksanannya sehingga diharapkan setiap kegiatan didukung sepenuhnya oleh aparat desa.

\section{Sosialisasi tentang pelaksanaan IbM} kepada mitra pengusaha trasi dan ibu-ibu PKK Desa Kramat.

Kegiatan ini bertujuan memberikan penyuluhan kepada ibu-ibu PKK dan pengusaha terasi tentang jiwa kewirausahaan. Materi ini penting untuk diberikan mengingat ibu-ibu PKK $75 \%$ sebagai ibu rumah tangga dan pengusaha terasi dalam pengelolaan usahanya juga belum dikelola secara baik. Diharapkan dari materi ini kan tumbuh usahawan baru dan usaha terasi dapat dikelola dengan baik dengan brand khas pulau mengare.

Penyuluhan pembuatan terasi dan hygienitas pembuatan terasi diberikan bertujuan agar terasi yang dihasilkan mempunyai kualitas yang bersaing dengan terasi dari daerah lain, disamping itu peserta pelatihan juga mempunyai pemahaman tentang dampak negatif makanan yang kurang hygienis tidak memenuhi standar makanan. Dalam kegiatan ini juga dijelaskan dampak negative penggunaan pengawet terasi dan campuran terasi yang tidak aman bagi kesehatan.

\section{Pelatihan Pembuatan Terasi secara Hygienis.}

Kegiatan ini bertujuan mengaplikasikan materi yang telah diberikan pada saat sosialisasi. Kelompok pengusaha Terasi melakukan pembuatan Terasi dengan menggunakan alat - alat dan bahan rebon yang hygienis dengan mulai memperhatikan tentang kebersihan dan kesehatan. Pelaksanaan kegiatan pelatihan pembuatan Terasi secara Hygienis pada tanggal 29 Juni 2015 di Kantor Desa Kramat dan dipantau secara langsung oleh bapak dan ibu Kepala Desa.

\section{Pelatihan Pengemasan dan Pelabelan} Terasi

Pelatihan kedua yang dilakukan adalah pelatihan pegemasan dan pelabelan Terasi. Tujuan dari kegiatan ini adalah untuk menunjukkan ke pada kelompok pengusaha terasi agar terasi yang dihasilkan bisa langsung diperjualbelikan dengan menggunakan branch baru khas Desa Mengare. Selama ini terasi yang dijual oleh Kelompok Pengusaha Terasi tidak mempunyai branch dan penjualannya dalam bentuk kiloan tidak terbungkus dengan hygienis. Pelaksanaan Pelatihan Pengemasan dan Pelabelan Terasi pada tanggal 29 Juni 2015 di Kantor Desa Kramat dan di pantau secara langsung oleh Bapak dan Ibu

Kepala Desa Kramat. Peserta Pelatihan ini adalah seluruh pengusaha Terasi di desa Kramat.

5. Pemberian materi strategi penjualan dan pembukuan sederhana

Kegiatan ini bertujuan untuk memberikan pengetahuan dan ketrampilan cara membuat pembukuan tentang usaha terasi secara sederhana dan penjualan secara on line. Selama ini pengusaha terasi tidak pernah melakukan pembukuan sehingga untung dan ruginya tidak kelihatan prinsip pengusaha yang penting ada uang untuk makan. Dalam melakukan penjualan juga masih konvensional yaitu trasi dijual ke tengkulat dalam bentuk gumpalan besar. Pengusaha tidak pernah mempersoalkan harga naik apa turun yang penting trasi laku dijual.

\section{Pendampingan Kelompok Terasi}

Kegiatan Pendampingan Kelompok Terasi bertujuan untuk memantau pelaksanaan hasil pelatihan oleh Kelompok Pengusaha Terasi. Pelaksanaan pendampingan ini dilakukan pada tanggal 13 Agustus 2015 dihadiri oleh para peserta kelompok Pengusaha terasi dan dipantau secara langsung oleh Bapak dan Ibu Kepada Desa Kramat. Hasil 
dari pendampingan yang dilakukan, para pengusaha Terasi sudah menerapkan cara pembuatan terasi secara Hygienis dengan memperhatikan alat dan bahan yang digunakan. Cara penjemuran rebon sudah memperhatikan kebersihan dan kesehatan. Sehingga sosialisasi dan pelatihan ini sudah berhasil diterapkan di kelompok Pengusaha Terasi. Hanya saja pengemasan dan pelabelan belum dilaksanakan. Kesulitan yang dihadapi oleh para pengusaha terasi adalah mencari rekanan untuk pemasaran terasi keluar desa Kramat.

7. Monitoring dan Evaluasi Kegiatan IbM Kelompok Pengusaha Terasi Monitoring dan Evaluasi Internal dilaksanakan pada tanggal 26 Juni 2015 oleh Kepala Lembaga Penelitian dan Pengabdian
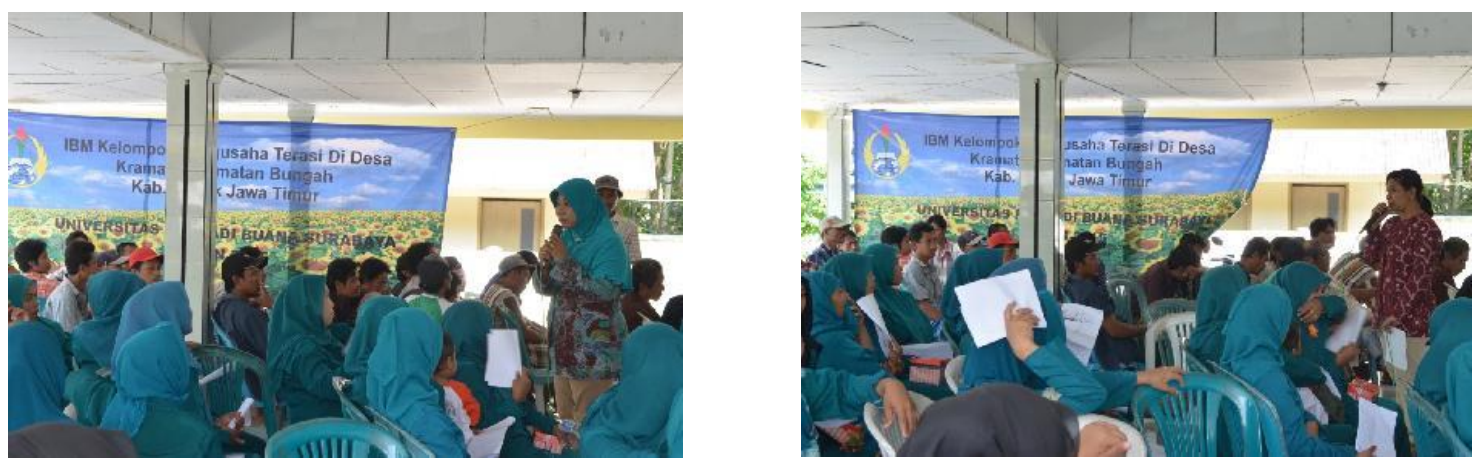

Gambar 1. Kegiatan Penyuluhan
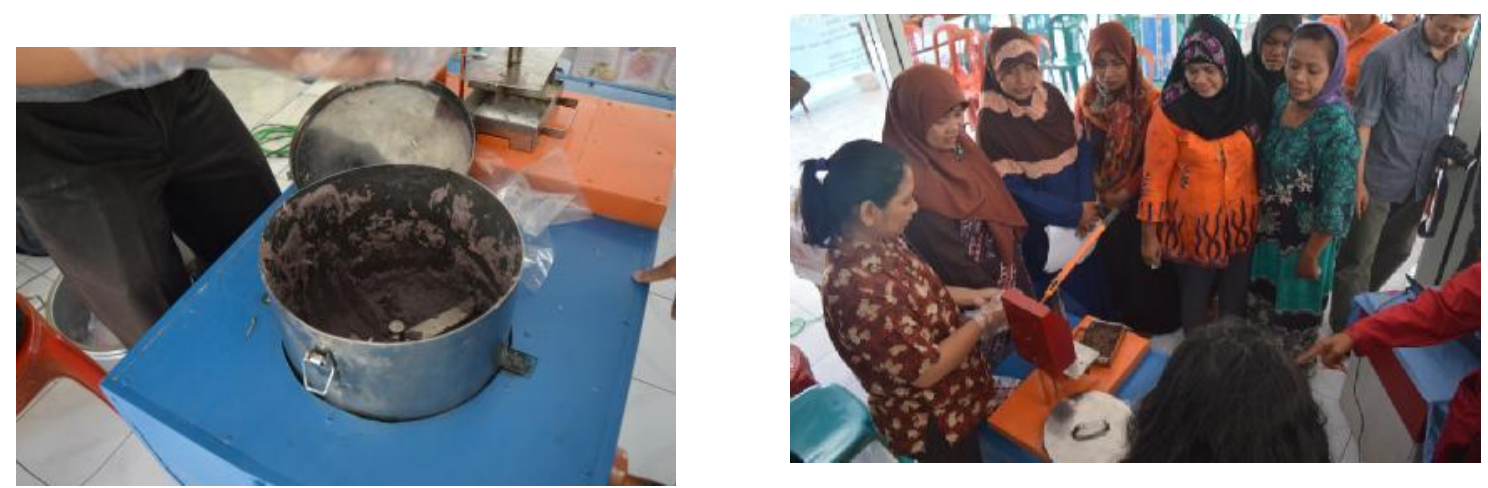

Gambar 2. Praktek Pembuatan Terasi 


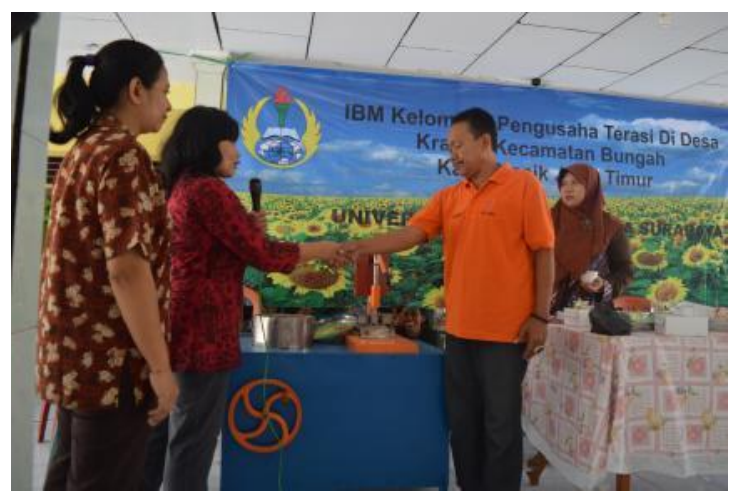

Gambar 3. Serah Teriam Mesin Penggiling dan Pencetak Terasi

\section{Pencapaian Target Luaran}

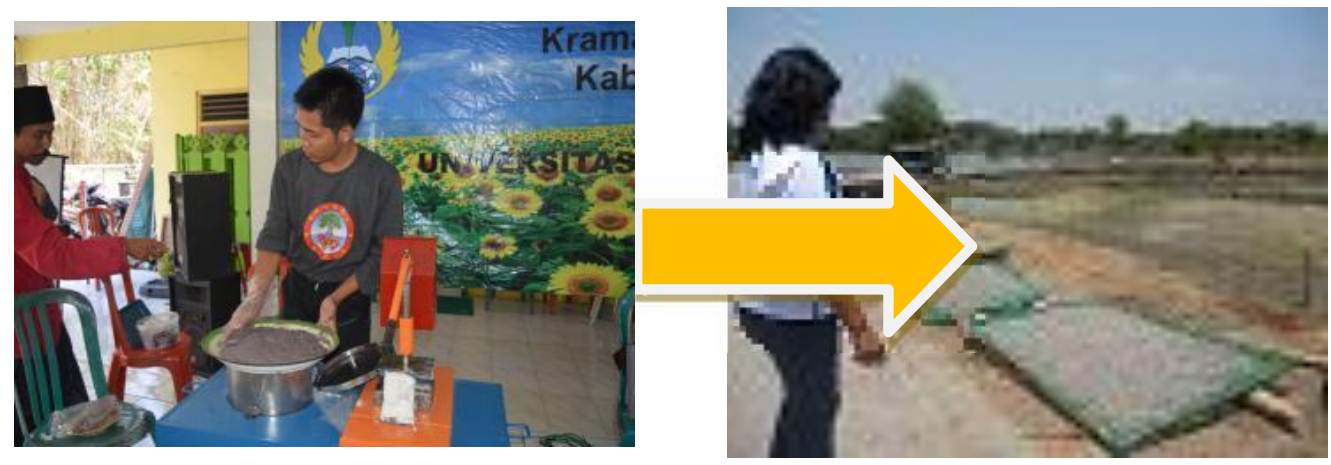

Gambar 4. Cara Penjemuran rebon terasi sudah memperhatikan kebersihan dan kesehatan

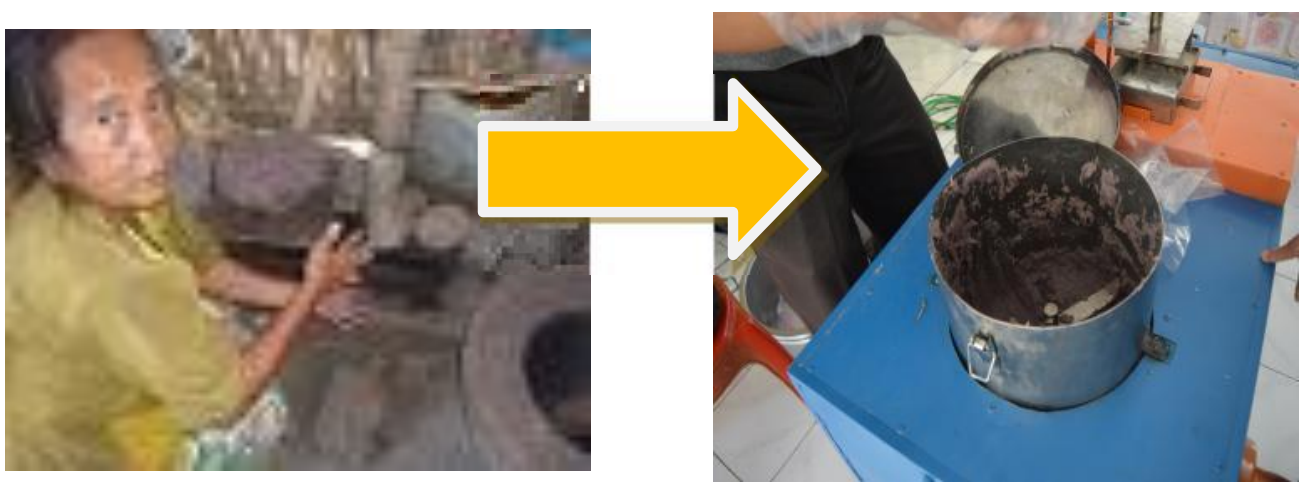

Gambar 5. Cara Penggilingan Terasi sudah menggunakan Mesin 
Hasil yang dicapai dalam kegiatan IbM Kelompok Pengusaha Terasi di Desa Kramat Kecamatan Bungah Kabupaten Gresik telah memenuhi target yang diharapkan. Sebelum adanya pelaksanaan IbM permasalah yang ada mengenai pengolahan bahan Terasi yang kurang hygienis dan juga alat yang digunakan untuk mengolah Terasi masih tradisional, saat ini dapat dilakukan dengan menggunakan mesin dan diolah secara hygienis. Pencetakan dan pelabelan sudah memenuhi target, dimana permasalahan sebelumnya tidak dilakukan pencetakan dan pelabelan, setelah dilaksanakan $\mathrm{IbM}$ telah ada Branch baru dari desa Kramat yaitu Terasi Asli Rebon dari Desa Kramat. Kegiatan IbM yang kami lakukan memperoleh hasil yaitu :
1. Masyarakat bisa melakukan pengolahan terasi dengan menggunakan mesin

2. Adanya perubahan perilaku masyarakat dalam mengolah makanan yang aman dan sehat.

3. Mitra mampu membuat Branch baru dan Label yang menarik dengan nama "Terasi Mengare".

4. Mitra sangat antusias mengikuti pelatihan dalam kegiatan $\mathrm{Ibm}$, dan masyarakat menginginkan adanya pelatihan untuk pemasaran dan meningkatkan ketrampilan dan pendapatan keluarga.

5. Masyarakat desa Kramat mempunyai keinginan untuk maju dan menambah wawasan lainnya.

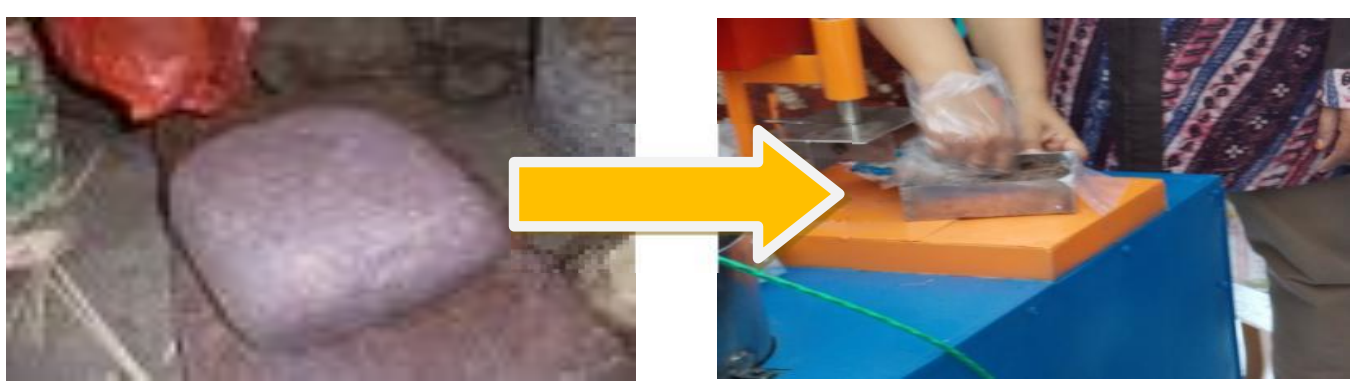

Gambar 6. Cara mencetak Terasi sudah menggunakan Mesin

\section{KESIMPULAN DAN SARAN}

\section{Kesimpulan}

Kesimpulan dari kegiatan IbM kelompok Pengusaha Terasi di Desa Kramat Kecamatan Bungah Kabupaten Gresik Jawa Timur adalah :

a. Pengusaha Terasi yang selama ini hanya memproduksi terasi secara tidak hygienis dan tidak memperhatikan kesehatan, setelah dilakukan kegiatan IbM, pengusaha Terasi melakukan kegiatan pengolahan terasi dengan menggunakan mesin dan dilakukan secara hygienis.

b. Bertambahnya pengetahuan pengusaha terasi tentang kebersihan, dan kesehatan pengolahan terasi secara hygienis.

c. Pengusaha terasi juga dapat memproduksi olahan terasi dengan branch baru, Terasi Mengare.

d. Bertambahnya pengetahuan pengusaha terasi melakukan pembuatan pencetakan dan label yang menarik pada produknya.

\section{Saran}

Saran yang dapat diberikan dalam kegiatan ini adalah : 
a. Masih perlu adanya kegiatan lain yang membutuhkan teknologi tepat guna sehingga kegiatan ini dapat dilanjutkan untuk dapat semakin meningkatkan produktifitas mitra.

b. Pemanfaatan sumber energy terbarukan saat ini masih minim, misalnya energy angin dan energy matahari, dimana potensi keduanya sangat banyak terdapat di negara ini.

c. Perlunya pelatihan khusus pemasaran dan cara - cara kerjasama dengan perusahaan produksi terasi lainnya.

\section{UCAPAN TERIMA KASIH}

Ucapan terima kasih disampaikan kepada : Penanggung jawab kegiatan Pengabdian Kepada Masyarakat DIPA Direktorat Jenderal Pendidikan yang telah membiayai kegiatan pelaksanaan Hibah Kompetitif IbM tahun anggaran 2015 yang tertuang dalam kontrak No SP DIPA 023.04.1.673453/2015 Revisi 01 tanggal 3

Maret 2015.

\section{DAFTAR PUSTAKA}

$$
\begin{aligned}
& \begin{array}{lll}
\text { Agriefishery. } & 2009 . & \text { Cara }
\end{array} \\
& \text { sendiri. } \\
& \text { http://zonaikan.wordpress.com } \\
& \text { /2009/09/18/cara-membuat- } \\
& \text { terasi-sendiri/ Diakses tanggal } \\
& 1 \text { Maret } 2014 \text { jam 20.00 WIB. } \\
& \text { Bagaimana Cara Membuat } \\
& \text { Terasi Yang Enak } \\
& \text { Dan Mudah. } \\
& \text { http://bagaimanacaramembuat. } \\
& \text { com/2011/05/24/bagaimana- } \\
& \text { cara-membuat- terasi-yang- } \\
& \text { enak-dan-mudah/ Diakses } \\
& \text { tanggal } 1 \text { Maret } 2014 \text { jam } \\
& \text { 20.00WIB. }
\end{aligned}
$$
Cara Membuat Terasi. http://nibras- satrio.blogspot.com/2013/07/c ara-membuat- terasi.html. Diakses tanggal 1 Maret 2013. Jam 20.30. WIB
Ma'ruf, M Dkk. 2013. Penerapan Produksi Bersih Pada Industri Pengolahan Terasi Skala Rumah Tangga Di Dusun Selangan Laut Pesisir Bontang. Jurnal Ilmu Perikanan Tropis Vol. 18. No. 2, April 2013 - ISSN 1402- 2006
Mimit.2008. Penerapan Mesin Penggiling Udang Kecil (Rebon) Semi Otomatis

\begin{tabular}{lrr} 
Sistem & Crew & Untuk \\
Pembuatan & Terasi & Di \\
Probolinggo. & Jurnal Mitra \\
Akademika. & Vol XII. \\
Fakultas & Perikanan & Dan \\
Kelauatan & \multicolumn{2}{c}{ Universitas } \\
Brawijaya & &
\end{tabular}

Suprapti, M. Lies. 2002. Teknologi Tepat Guna Membuat Terasi. Kanisius. Yogyakarta

Usaha Pembuatan Terasi http://www.wirausahaimpian.com/2013/ 07/usaha- pembuatan-terasi.html. Dikases 1 Maret 2014 jam 21.00 WIB. 
